\title{
PERSEPSI SISWA SMA TERHADAP PENSI SEKOLAH DAN PEMETAAN PENGETAHUAN DAN PEMAHAMAN SISWA TENTANG EVENT ORGANIZING
}

\author{
Syauqy Lukman \\ Lilis Puspitasari \\ FAKULTAS ILMU KOMUNIKASI \\ UNIVERSITAS PADJADJARAN
}

\begin{abstract}
ABSTRAK
Pensi atau pentas seni, adalah kegiatan yang lazim dilakukan oleh sejumlah sekolah di Indonesia. Penyelenggaraan pensi untuk beberapa sekolah tertentu melibatkan sumber daya yang sangat besar dari aspek sumber daya, khususnya sumber daya finansial. Penyelenggaraan pensi sendiri tuntutannya semakin mendekati event profesional seperti yang dilakukan oleh event organizer (EO) profesional, padahal pelajar sekolah bukanlah tenaga EO profesional.

Penelitian ini berusaha menangkap bagaimana persepsi siswa SMA tentang penyelenggaraan pensi dan berusaha menguji pengetahuan seputar penyelenggaraan pensi. Hasil menunjukkan bahwa pensi sekolah dipersepsi sebagai sesuatu yang penting bagi siswa, namun siswa menilai pihak sekolah dan guru tidak menganggap pensi sekolah sebagai sesuatu yang penting. Pensi sekolah dianggap sebagai sebuah kegiatan yang tidak sekedar buangbuang sumber daya di mata siswanya. Dalam mengapresiasi pensinya sendiri, responden cenderung setuju bahwa pensi mereka lebih baik dibanding sekolah lain, meskipun angka yang menjawab tidak tahu juga tinggi. Sehubungan dengan kompetensi mengelola kepanitiaan, responden cenderung merasa bahwa mereka mampu mengelola event, meskipun angka yang menjawab tidak tahu juga tinggi. Lebih lanjut, sebagian besar merasa mereka perlu mendapatkan pelatihan event organizing.

Meskipun mereka merasa mampu, namun dalam konteks pemetaan pengetahuan siswa seputar pengelolaan event, level pengetahuan responden ada di angka yang cukup rendah.

Diharapkan melalui penelitian ini, dapat memberikan gambaran mengenai bagaimana siswa SMA di Bandung memiliki persepsi tentang pensi dan melalui pengujian, dapat menjadi referensi kebijakan terhadap dinas dan instansi terkait, yang berhubungan dengan penyelenggaraan di sekolah.
\end{abstract}




\section{PENDAHULUAN}

\section{Fenomena pensi di kalangan pelajar}

Pensi adalah kegiatan yang sangat lazim dilakukan oleh siswa usia SMA, di mana dalam beberapa tahun belakang ini, penyelenggaraan Pensi yang baik menjadi semacam achievement bagi siswa sekolah yang mengadakannya, dan Pensi yang baik menjadi sarana eksistensi dan juga adu gengsi antar sekolah. Hal tersebut juga dinyatakan dalam artikel di lembaran Kompas Muda edisi 23 Januari 2015 (http://beta286.print.kompas.com/ muda/2015/01/23/pensi-ajang-pamer/).

Pentas seni atau pensi sering kali menjadi ajang "pamer" atau unjuk gigi bagi sekolah-sekolah. Lewat pensi, panitia secara tidak langsung ingin menunjukkan keberadaan sekolah mereka kepada masyarakat. Tapi, di luar itu, sekolah memberi kesempatan kepada siswa yang jadi panitia pensi untuk belajar berorganisasi, mengatur keuangan, dan kemandirian. Tidak tanggung-tanggung, uang yang dikelola ratusan juta rupiah.

Musik merupakan seni yang palih mudah dicerna masyarakat pada umumnya. sehingga musik menjadi sesuatu yang diagungkan, apalagi oleh siswa-siswa sekolah menengah di Indonesia. Mengapa melibatkan siswa sekolah menengah? Karena penggunaan frase pentas seni sekarang selalu diafiliasikan kepada acara yang dibuat siswa sekolah menengah. Bisa dilihat dari berbagai acara yang mengusung nama pentas seni di kalangan siswa sekolah menengah. Sehingga pensi seringkali identik dengan panggung musik. Pensi yang menghadirkan musisi-musisi terkenal, notabene dengan biaya yang sangat mahal, menghadirkan prestise tersendiri bagi siswa sekolah yang berhasil menghadirkannya.

Pensi memang telah berubah terkait dengan penyelenggaraannya. Pensi biasanya diadakan di sekolah sehingga biayanya lebih murah. Namun, sekitar sepuluh tahun terakhir, mulai muncul tren mengadakan pensi di luar sekolah. Panitia menyewa tempat seperti gelanggang olahraga atau gedung pertemuan tempat biasa festival musik nasional digelar.

Tentang penampil dalam pensi juga berubah. Dahulu, pensi menjadi kesempatan utama menampilkan kepiawaian siswa sekolah setempat dalam menari, menyanyi, main band, berpuisi, dan lainnya. Sekarang, sekolah-sekolahternamamemilihmenghadirkan band-band yang sedang digemari remaja sebagai penampil utama. Ujung-ujungnya perubahan itu membutuhkan dana besar yang mengharuskan panitia yang terdiri atas para siswa berjuang mencari biaya.

Tentang tempat penyelenggaraan pensi, sekolah di Jakarta dan kota besar sudah biasa melakukannya di luar sekolah. Menurut Erik Darmawan, siswa SMA Pangudi Luhur 1 Jakarta yang menjadi Ketua PL Fair 2014, pensi di sekolahnya semula diadakan di sekolah. Baru awal tahun 2000, panitia memilih mengadakan acara di luar sekolah (http://beta286.print. kompas.com/muda/2015/01/23/pensiajang-pamer/). 


\section{Pensl Menurut Pelajar SMA}

Apakah sekolahmu pernah mengadakan pentas seni? (dalam persen)

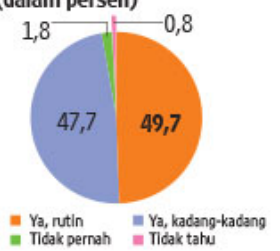

- Tilak pernah $=$ Milak tahu

Apakah pentas seni tersebut diselenggarakan di lingkungan sekolah saja atau di luar sekolah juga? (dalam persen)

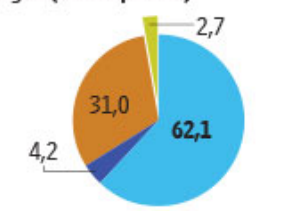

=DI dalam sekolah - Dil luar sekolah - Pernah di sekolah dan dil luar sekolah

Metode Penelitian: Pengumpulan pendapat melalui survei berupa angket dilakukan Litbang "Kompas" dari Oktober hingga November 2014. Sebanyak 1324 responden adalah pelajar Seberapa SMA Manesi Selatan Kederajat Barat, Sumatera Selatan, dan Jakarta. Hasil angket ini tidak dimaksudkan untuk mewakili pendapat seluruh pelajar SMA Indonesia.

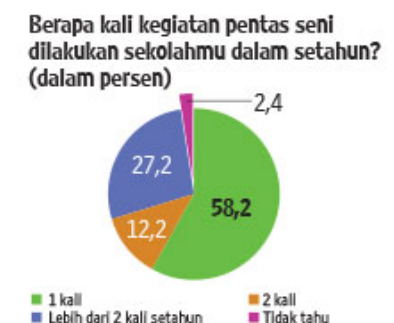

- Lebilh dari 2 kall setahun

Apakah dalam pentas seni tersebut mengundang bintang tamu dari luar sekolah? (dalam persen)

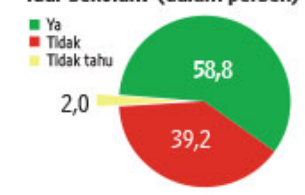

Apakah tujuan dari diadakannya pentas seni tersebut? (dalam persen)

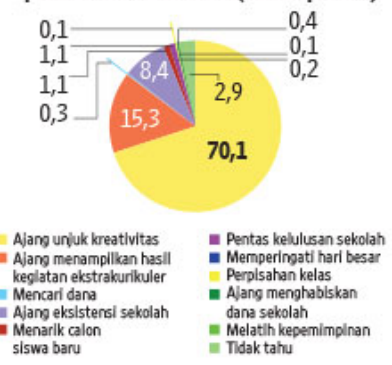

Siapa penyelenggara kegiatan pentas seni? Penyelenggara wilayah sekolah (dalam persen)

- Jakarta 07 Sumatera Selatan

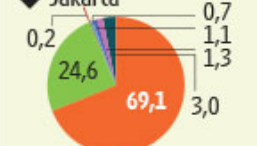

$0,4^{8,9} 7,8^{0,7}$

0,7

37,9

- Sulawesi Selatan Kalimantan Barat

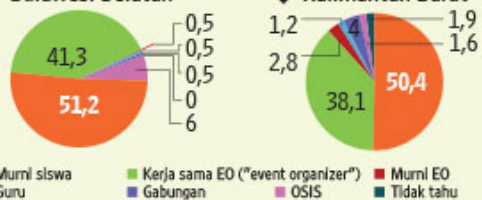

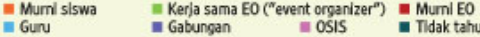

Berasal dari mana sebagian besar sumber dananya? (dalam persen)

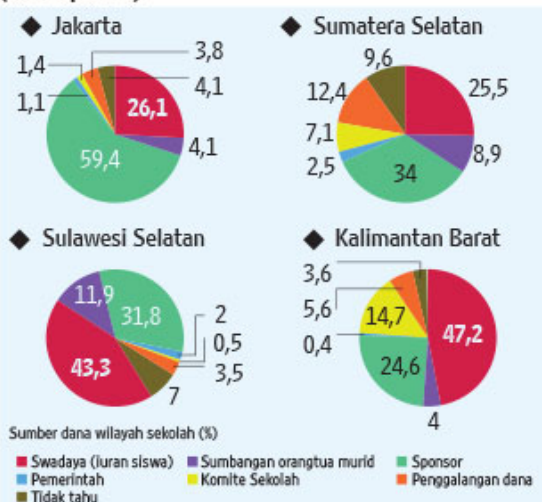

Gambar 1. Rekapitulasi Survey Pensi

Sumber: Divisi Litbang Harian Kompas, 2015

Bicara mengenai kepentingan siapa yang dihadirkan dalam kegiatan ini, dulu orientasi pensi adalah kepentingan siswa, di mana penyelenggaraan acara menjadi ajang 'eksis' dari para siswanya. Namun kini, eksistensi tersebut terwujud dalam bentuk yang lain, di mana kini kepentingan siswa tersebut diwakili dengan sebisa mungkin membuat pagelaran yang baik atas dasar kepuasan khalayak umum. Hal tersebut ternyata dinilai menjadi sesuatu yang dibanggakan.

Dalam sebuah survey yang dilakukan divisi Litbang harian Kompas pada Oktober-November 2014, melibatkan 1.324 responden siswa SMA di Indonesia, dengan responden terbanyak sebas berasal dari Sulawesi Selatan, Jakarta, Kalimantan Barat, dan Sumatera Selatan, didapatkan sejumlah insight menarik tentang persepsi siswa SMA tentang pensi (lihat Gambar. 1).

Dari hasil rekapitulasi survey tentang pensi di mata siswa SMA, beberapa poin penting adalah Sebagai berikut:

1. Sebagian besar pentas seni SMA, yaitu 58,2\% diadakan setahun sekali setidaknya, dan mengundang bintang tamu dari luar sekolah (58,8\%). Prosentase tertinggi mengenai tujuan mengadakan pensi adalah ajang unjuk kreatifitas adalah 70,1\%, sementara sebagai ajang unjuk hasil 
ektrakurikuler adalah sebesar 15,3\%. Hanya $8,4 \%$ siswa yang merasa bahwa pensi itu adalah ajang sekolah untuk 'eksis'. Hal ini sangat tidak konsisten dengan beberapa pensi yang diamati tim peneliti, memberikan porsi bintang tamu lebih banyak dan lebih 'menjual' nama-nama tenar artis ketimbang unjuk kreatifitas atau ekskulnya. Hal ini dapat dilihat dari beberapa poster pensi SMA yang cukup terpandang di Bandung. Porsi informasi tentang unjuk kreatifitas dan ekskul dari sekolah justru minim (lihat Gambar 2.).

2. Kegiatan pentas umumnya diadakan di dalam lingkungan sekolah. Namun, tak menutup kemungkinan acara ini diadakan di luar sekolah. Bahkan ada sekelompok siswa yang mengaku

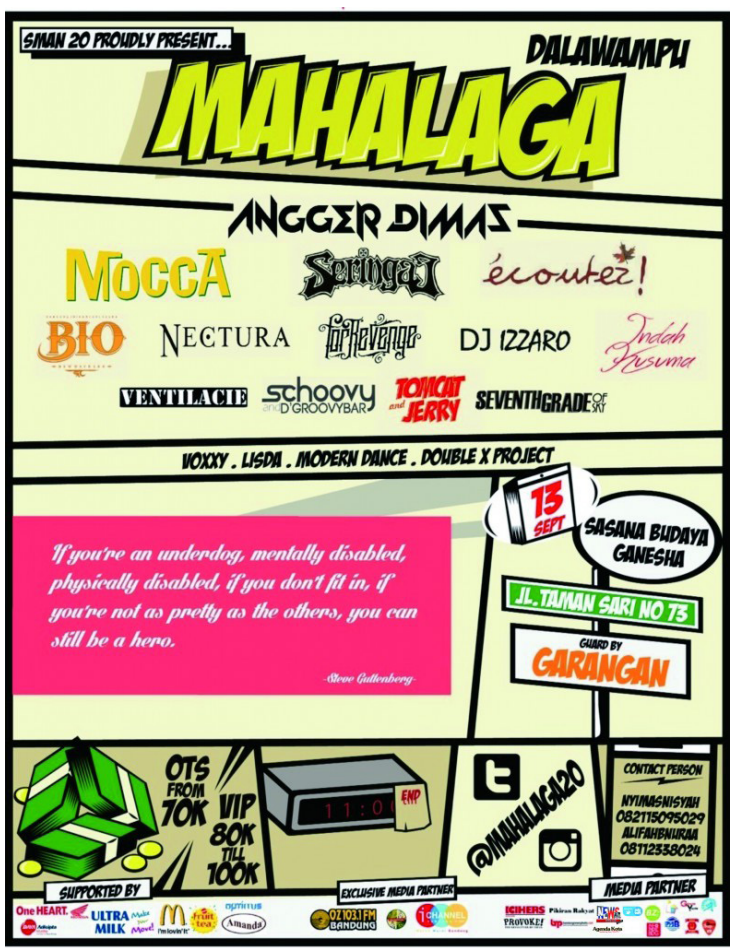

sekolahnya pernah menyelenggarakan pensi di dalam dan di luar lingkungan sekolah. Demi memeriahkan acara dan menyedot banyak pengunjung, kegiatan pensi kerap mengundang bintang tamu dari luar sekolah. Tak jarang, artis atau band yang lagi ngetop, baik berskala nasional ataupun lokal tampil memeriahkan acara.

3. Masih dari survey tersebut, salah satu faktor penting dalam suksesnya acara pensi adalah dana. Tanpa dana, kegiatan unjuk kreativitas ini tidak akan berjalan. Sebanyak 42,8 persen dari seluruh responden menyatakan masih mengandalkan sponsor untuk mengadakan pensi. Ada juga yang berusaha menyelenggarakan kegiatan pensi dengan bermodalkan dana sendiri.

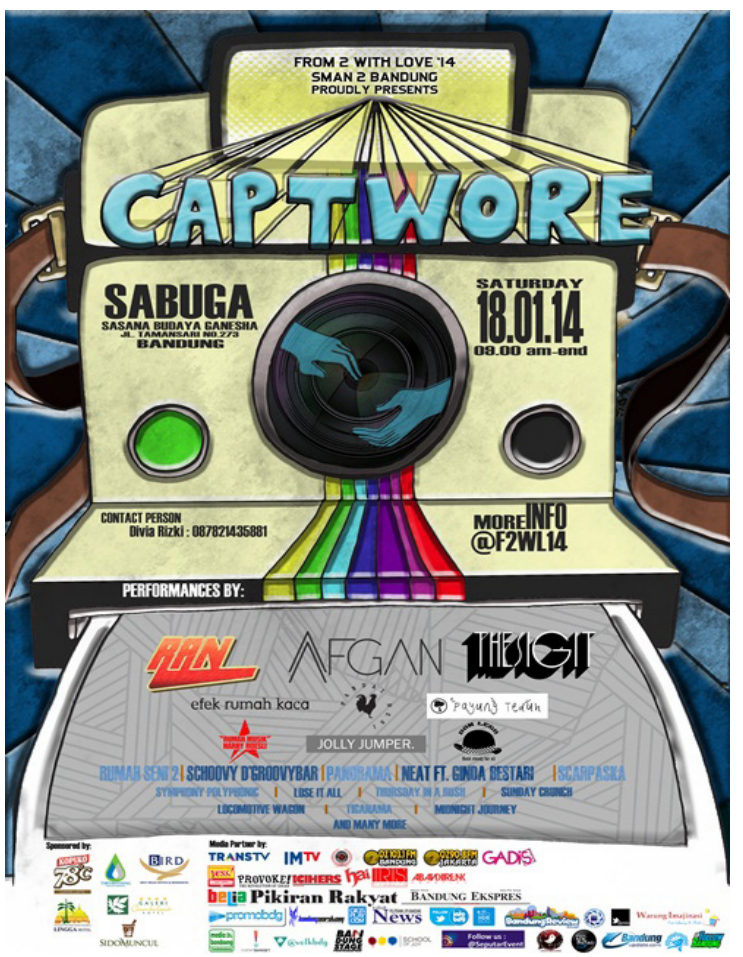

Gambar 2.

Poster Pensi SMAN 20 Bandung (2015) dan SMAN 2 Bandung (2014) 
Selain bekerja sama dengan sponsor, tak sedikit panitia pensi yang bekerja sama dengan event organizer (EO), terutama pensi yang diselenggarakan di Provinsi DKI Jakarta, Sulawesi Selatan, dan Kalimantan Barat. Bermitra dengan pihakEOyang berpengalaman tidak saja lebih memudahkan penyelenggaraan, tetapi juga bisa belajar banyak dari mereka.

Seperti yang dapat dilihat pada Gambar 2., terdapat inkonsistensi antara persepsi siswa SMA yang menganggap pensi sekolahnya sebagai ajang unjuk kreatifitas $(70,1 \%)$ dan ajang unjuk kebolehan ekskul $(15,3 \%)$ jika dibandingkan dengan temuan yang direpresentasikan dengan poster publikasi pensi yang menekankan pada artis bintang tamu. Begitu juga dalam penjadwalan, aksi dari siswa, baik ekskul atau sajian seni lainnya, selalu mendapatkan jadwal yang kurang baik, dan porsinya lebih sedikit ketimbang bintang tamu.

Meskipun tren yang muncul dalam penyelenggaraan pensi sepertinya menunjukkan bahwa pelajar sekolah memiliki preferensi untuk menampilkan artis-artis dan kesenian modern, khususnya musisi, namun banyak juga sekolah yang memilih untuk menampilkan seni tradisional. Contohnya SMAN 3 Kota Cirebon, yang lebih memilih menampilkan muatan lokal dengan bekerja sama dengan seniman lokal dalam menampilkan tradisional (http://www.pikiran-rakyat. com/serial-konten/8671).
Yang menjadi masalah adalah, siswa SMA adalah siswa SMA, bukan event organizer profesional yang sudah terbiasa mengelola acara-acara dengan level profesionalisme tinggi. Siswa SMA belum paham tentang perencanaan, pelaksanaan, dan evaluasi dalam tahapan event organizing. Padahal, event-event pensi di sejumlah sekolah menengah terpandang di Bandung, salah satunya pensi SMAN 1 Bandung, seringkali melibatkan uang dalam jumlah yang sangat besar dan membutuhkan pemahaman tentang event organizing secara komprehensif.

Hal ini menjadi peluang bisnis bagi event organizer (EO) di mana banyak yang menawarkan jasanya untuk menjadi konsultan atau mengelola eventnya keseluruhan. Dalam artikel yang dimuat pada 29 September 2014, (http://www.haionline.com/Hai/Feature/Skulizm/SekolahLo-Mau-Bikin-Pensi-Hati-hati-Sama-EOyang-Lo-Pilih/) reporter majalah remaja Hai, Satria Perdana menyatakan bahwa EO, bisa mengutip fee yang cukup besar, yaitu sampai 10\%-20\% dari harga bintang tamu dan sewa sound system, panggung dan logistik lainnya.

Lebih parahnya lagi, fenomena lain yang muncul adalah ketika guru sekolah berubah fungsi menjadi makelar artis dan makelar logistik pensi. Masih dalam terbitan yang sama dari majalah Hai, lewat sebuah reportase investigatif, terkuak fakta beberapa orang guru yang 'bermain' dalam hal pengelolaan pensi. Penyelewengan yang dilakukan bisa dalam pencarian sponsor, 
pengadaan logistik dan/atau konsumsi, atau agreement dengan artis/bintang tamu.

Banyaknya issue dalam kegiatan pensi sekolah membuat sejumlah sekolah, bahkan beberapa unit pelaksana dinas daerah memberikan kebijakan dan aturan beragam yang berhubungan dengan pelaksanaan pensi. Dinas pendidikan kota Bandung, memberikan larangan kepada pihak sekolah untuk mengadakan pensi sampai malam. Beberapa sekolah juga memiliki aturan yang sangat ketat sehubungan dengan penyelenggaraan pensi ini.

Peneliti merasa kurangnya pemahaman dan pengetahuan tentang pensi menjadi satu informasi yang krusial untuk membantu menyelesaikan fenomena sosial ini. Selain itu, perlu juga dipetakan bagaiman persepsi siswa SMA mengenai pensi sekolah secara lebih komprehensif dan menyeluruh, agar dapat menjadi dasar penelitian lebih lanjut untuk penyikapan fenomena sosial ini.

Berdasarkan uraian di atas, maka penelitian ini berusaha memetakan persepsi siswa SMA terhadap pensi sekolah mereka. Selain itu, penelitian ini juga akan mengukur tingkat pemahaman dan pengetahuan siswa SMA tentang event organizing.

\section{Tujuan Penelitian}

1. Untuk mendapatkan data yang deskriptif secara komprehensif tentang Persepsi siswa SMA terhadap pensi sekolahnya

2. Untuk mengukur pengetahuan dan pemahaman siswa SMA terhadap aspek-aspek penting event organizing dalam penyelenggaraan pensi

\section{METODE PENELITIAN}

Tipe penelitian ini adalah penelitian deskrtiptif dengan data kualitatif dan kuantitatif yang dilakukan dengan tujuan menggambarkan atau mendeskripsikan obyek dan fenomena yang berkaitan dengan persepsi dan pengetahuan siswa SMA berkenaan dengan pensi sekolahnya.

Metode penelitian deskriptif adalah salah satu metode penelitan yang banyak digunakan pada penelitian yang bertujuan untuk menjelaskan suatu kejadian. Seperti yang dikemukakan oleh Sugiyono (2011) "penelitian desktiptif adalah sebuah penelitian yang bertujuan untuk memberikan atau menjabarkan suatu keadaan atau fenomena yang terjadi saat ini dengan menggunakan prosedur ilmiah untuk menjawab masalah secara aktual". Sedangkan, Sukmadinata (2006) menyatakan bahwa metode penelitian deskriptif adalah sebuah metode yang berusaha mendeskripsikan, menginterpretasikan sesuatu, misalnya kondisi atau hubungan yang ada, pendapat yang berkembang, proses yang sedang berlangsung, akibat atau efek yang terjadi atau tentang kecenderungan yang sedang berlangsung.

Alasan peneliti manggunakan jenis penelitian deskripsi adalah karena dengan penelitianinimampumemberikan gambaran 
yang menyeluruh dan jelas terhadap satu situasi dengan situasi sosial yang lain atau dari waktu tertentu dengan waktu yang lain, atau dapat menemukan pola-pola hubungan antara aspek tertentu dengan aspek yang lain, dan dapat menemukan hipotesis dan teori. Dari data deskriptif tersebut diharapkan dapat dihasilkan insight yang baik untuk perumusan hipotesis dan teori.

Adapun jenis data dalam penelitian ini ada dua macam, yaitu jenis data primer dan jenis data sekunder. Yang dimaksudkan dengan jenis data primer adalah jenis data tentang persepsi subyek sehubungan dengan pensi sekolah dan level pengetahuannya tentang event organizing. Dari data ini, akan diidentifikasi persepsi obyek penelitian atas konsep pensi sekolah, dan tingkat pengetahuan serta pemahaman mereka atas tata cara event organizing.

Data sekunder adalah data yang memuat identitas subyek dan beberapa informasi penting lainnya sebagai referensi triangulasi data. Diantara lain didapatkan dari sumber literatur, riset terdahulu, khususnya yang berhubungan dengan topik penelitian.

Untuk keabsahan data peneliti menggunakan telaah teknik triangulasi sumber, yaitu penggunaan sumber yang berbeda untuk mengumpulkan data sejenis. Pengumpulan data kualitatif dilakukan dengan cara observasi dan wawancara mendalam. Wawancara dengan beberapa narasumber kunci atau key informants dengan kriteria informan meliputi: 1) Pengamat sosial dan pendidikan, khususnya yang banyak terlibat dengan aktifitas penyelenggaraan pensi di sekolah; 2) Psikolog/ahli yang mengamati prilaku di kalangan remaja/mahasiswa; 3 ) representasi dari institusi yang memiliki kepentingan kebijakan penyelenggaraan pensi, dalam hal ini adalah pihak dinas pendidikan Jawa Barat dan Kota Bandung.

Instrumen yang digunakan untuk penelitian deskriptif ini adalah berupa kuesioner dengan pertanyaan tertutup. Sedangkan untuk data kualitatif, dirumuskan kuisioner dengan pertanyaan terbuka dan panduan wawancara. Panduan wawancara dibuat untuk memagari alur wawancara agar tetap focus pada bahasan seputar persepsi tentang pensi dan pengetahuan event organizing. Aspek yang diteliti yaitu aspek kognisi dan afeksi dari siswa tentang pensi, pengetahuan dan pemahaman siswa tentang event organizing, serta beberapa aspek lainnya yang berkaitan dengan topik penelitian.

Teknik pengumpulan data menggunakan bukti multi sumber (triangulasi) artinya teknik pengumpulan data yang bersifat menggabungkan dari berbagai teknik pengumpulan data dan sumber data yang telah ada. Teknik triangulasi berarti peneliti menggunakan teknik pengumpulan data yang berbedabeda untuk mendapatkan data dari sumber yang sama. Peneliti akan menggunakan observasi partisipatif, wawancara mendalam, dan dokumentasi untuk sumber data yang sama secara serempak. 


\section{Teori Interaksionisme Simbolik}

Secara sepintas, teori ini menilai bahwa manusia termotivasi untuk bertindak berdasarkan makna-makna yang diberikan kepada orang, benda, dan kejadiankejadian (West, et.al, . Makna-makna ini tercipta dalam bahasa di mana manusia berkomunikasi dengan orang lain dalam konteks interpersonal, dan intrapersonal (self-talk). Bahasa memungkinkan manusia untuk membangun kesadaran atas diri dan interaksi dengan orang lain dalam lingkungannya.

\section{Tema dan Asumsi Teori Interaksi Simbolik}

Gagasan teori ini berangkat dari diri manusia dan bagaimana hubungannya dengan masyarakat. LaRossa, et. al (1993) mengedepankan tiga tema utama dalam kajian Interaksi Simbolik.

- Pentingnya makna bagi prilaku manusia

- pentingnya konsep diri

- hubungan antara individu dengan lingkungannya

Membahas tentang komunikasi dengan perspektif ini, dihasilkan turunan teori dalam cara menyampaikan maksud dan tujuan dari komunikator kepada komunikan yakni interaksi simbolik. Esensi dari interaksi simbolik yakni adalah suatu aktivitas yang merupakan ciri khas manusia yakni komunikasi atau pertukaran simbol yang diberi makna (Mulyana, 2003:59). Paham interaksionisme simbolik memberikan banyak penekanan pada individu yang aktif dan kreatif ketimbang pendekatan- pendekatan teoritis lainnya. Paham interaksionisme simbolik menganggap bahwa segala sesuatu tersebut adalah virtual. Semua interaksi antar individu manusia melibatkan suatu pertukaran simbol. Ketika kita berinteraksi dengan yang lainnya, kita secara konstan mencari "petunjuk" mengenai tipe perilaku apakah yang cocok dalam konteks itu dan mengenai bagaimana menginterpretasikan apa yang dimaksudkan oleh orang lain. Interaksionisme simbolik, mengarahkan perhatian kita pada interaksi antar individu, dan bagaiman hal ini dipergunakan untuk mengerti apa yang orang lain katakan dan lakukan kepada kita sebagai individu.

Teori ini menurut peneliti dirasa paling sesuai jika digunakan untuk mendekati konstruk persepsi siswa SMA terhadap pensi SMA sekolah. Bagaimana interaksi antar individu manusia menghasilkan pemaknaan siswa SMA atas pentingnya pensi sekolah, bagaimana konsep diri mereka terhadap pensi sekolah, dan bagaimana hubungan antara individu dengan lingkungannya, dalam hal ini siswa SMA dengan lingkungan sekolah dan pergaulannya, berkontribusi terhadap "apa itu Pensi sekolah.”

\section{Objek Penelitian}

\section{Populasi}

Populasi dari penelitian ini adalah seluruh pelajar usia SMA yang rutin melaksanakan kegiatan event organizing yaitu pensi sekolah. Berdasarkan data yng diperoleh dari website resmi dinas 
pendidikan Jawa Barat, diperoleh data terdapat $226 \mathrm{SMA} /$ se-derajat dengan estimasi jumlah siswa sebanyak 35.000-an siswa per angkatannya, dengan perkiraan sebanyak 105.000-an siswa aktif (kelas 1-3) di Kodya Bandung.

\section{Sampel}

Memperhatikan jumlah sampel yang sangat besar dan sangat banyaknya SMA/sederajat yang tersebar, maka dalam penelitian ini ditentukan sejumlah kriteria pemilihan sekolah yang akan dijadikan sampel demi kemudahan riset. Hal ini mempertimbangkan;

1). Kemampuan peneliti dilihat dari waktu, tenaga dan dana

2). Sempit luasnya wilayah pengamatan dari setiap subyek, karena hal ini menyangkut banyak sedikitnya dana.

3). Besar kecilnya resiko yang ditanggung oleh peneliti untuk peneliti yang resikonya besar, tentu saja jika samplenya besar hasilnya akan lebih baik (Sugiyono, 2011)

Berdasarkan pra-riset, dimana peneliti melakukan pengamatan sejumlah pensi yang sudah dilakukan oleh SMA/sederajat di Bandung dan berkat saran dari sejumlah pelaku media yang mengamati fenomena pensi di Bandung, maka ditentukan 5 (lima) buah sekolah yang siswanya akan dijadikan objek penelitian ini berdasarkan pertimbangan:

1. Konsistensi dan kontinuitas pelaksanaan pensi

2. Skala pelaksanaan pensi dari aspek budget dan sumber daya lainnya (venue, bintang tamu yang diundang, logistik yang digunakan)

3. Tradisi/sejarah pelaksanaan pensi yang sudah berlangsung tiap tahun/secara periodik

4. Sampel yang dipilih adalah anggota OSIS dan/atau siswa SMA yang terlibat dalam pelaksanaan pensi sekolah.

Sekolah yang dipilih adalah: SMAN 1 Bandung, SMAN 2 Bandung, SMAN 5 Bandung, SMAN 20 Bandung, dan SMA Taruna Bakti Bandung. Dengan demikian, dapat dikatakan bahwa metode sampling dalam penelitian ini adalah purposive sampling, di mana tata cara pengambilan sampel dilakukan berdasarkan sampel yang memiliki ciri.kriteria sesuai dengan tujuan penelitian.

Untuk kemudahan penelitian, maka ditentukan kuota sampel sebanyak 100 orang, dengan sampel sebanyak 20 orang tiap sekolah, berdasarkan pertimbangan keterbatasan peneliti dari aspek sumber daya waktu dan tenaga.

\section{Teknik Pengumpulan data}

Pengumpulan data yang akan dilakukan dalam penelitian ini, menggunakan metode sebagai berikut:

1. Observasi yang dilakukan dalam mengumpulkan data dari objek penelitian, dalam hal ini adalah memantau fenomena seputar event organizing di kalangan remaja usia SMA di Bandung

2. Pembagian kuisioner yang mengupas persepsi dan pengetahuan objek 
penelitian seputar event organizing

3. Studi literatur dengan mencari datadata referensi ilmiah dan populer seputar penelitian, baik dari literatur buku, internet, dan dokumen lainnya.

\section{Teknik Analisis data}

Penelitian ini menggunakan teknik analisis data deskriptif kuantitatif. Menurut Sugiyono (2011, Penelitian diskriptif adalah penelitian yang dilakukan untuk mengetahui nilai variabel mandiri, baik satu variabel atau lebih (independen) tanpa membuat perbandingan, atau menghubungkan dengan variabel yang lain. Sedangkan penelitian kuantitatif, adalah penelitian dengan memperoleh data yang berbentuk angka atau data kualitatif yang diangkakan.

\section{HASIL DAN PEMBAHASAN}

Berdasarkan kuisioner yang telah disebarkan kepada 100 orang siswa dari SMAN 1, SMAN 2, SMAN 5, SMAN 20, dan SMA Taruna Bakti Bandung, didapat hasil dengan rekapitulasi sebagai berikut sehubungan dengan hal-hal yang perlu dijawab dalam penelitian ini. Variabel yang diukur adalah persepsi dan pengetahuan siswa mengenai hal-hal yang berhubungan dengan pengelolaan pensi sekolah. Persepsi diukur dengan menggunakan skala Likert dengan lima item pilihan, sedangkan uji pengetahuan dilakukan dengan memberikan pertanyaan pilihan benar-salah, di mana jawaban yang benar diberikan nilai 1 dan jawaban salah diberikan nilai 0 . Nilai total dari jawaban akan menunjukkan kecenderungan dari sampel mengenai pengetahuan dari pertanyaan yang ditanyakan (Sugiyono, 2003).

\section{Persepsi siswa terhadap pensi}

Variabel iniberusaha dideskripsikan dalam 4 dimensi yang diwakili beberapa item pertanyaan berdasarkan hasil interview dari pengamat pensi sekolah, diukur menggunakan skala Likert (Sugiyono, 2003) yaitu:

- Urgensi Pensi

- Pensi dan sumber daya

- Apresiasi Pensi masing-masing sekolah

- Pensi dan kompetensi kepanitiaan

Keempat dimensi pengukuran tersebut merupakan hasil interpretasi peneliti berdasarkan pada interview dengan Tisha Anwar, reporter suplemen Belia Pikiran Rakyat, yang telah mengamati fenomena pensi SMA selama 15 tahun dalam profesinya sebagai wartawan ${ }^{1}$.

Dimensi 'urgensi pensi', mengukur seberapa penting pensi dalam pandangan sampel sehubungan dengan kesehariannya. Dimensi 'pensi dan sumber daya' menjelaskan bagaimana persepsi sampel sehubungan dengan pensi dan kaitannya dengan penggunaan sumber daya uang dan waktu. 'Apresiasi Pensi', adalah penilaian mengenai pensi sampel terhadap pensi sekolahnya sendiri. 'Pensi dan kompetensi' adalah dimensi yang mengukur bagaimana persepsi para siswa terhadap kemampuan dirinya masing-masing dalam pengelolaan pensi.

1 Interview dengan Tisha Amelia Anwar, reporter Belia Pikiran Rakyat, Agustus 2015 


\section{Urgensi Pensi}

Dimensi 'urgensi pensi' diwakili dengan 2 (dua) item pertanyaan tertutup, mengukur apakah pensi itu penting bagi sekolah dan guru, serta apakah pensi itu penting bagi para siswa. Satu pertanyaan terbuka menjelaskan mengenai urgensi pensi berdasarkan kegiatan pilihan yang dipersepsikan oleh sampel siswa.

Berikut ini adalah rekapitulasi hasil pengolahan data terhadap variabel persepsi urgensi pensi untuk pertanyaan tertutup:

\begin{tabular}{|l|r|}
\hline \multicolumn{2}{|l}{$\begin{array}{l}\text { Menurut saya, pensi sekolah itu penting bagi } \\
\text { sekolah dan gurunya }\end{array}$} \\
\hline Sangat tidak setuju & 52 \\
\hline Tidak setuju & 45 \\
\hline Tidak Tahu & 2 \\
\hline Setuju & 1 \\
\hline Sangat Setuju & 0 \\
\hline Jumlah & $\mathbf{1 0 0}$ \\
\hline
\end{tabular}

Tabel 1. Rekapitulasi urgensi pensi di mata siswa terhadap sekolah dan guru

\begin{tabular}{|l|r|}
\hline \multicolumn{2}{|l|}{ Menurut saya, pensi sekolah itu penting bagi } \\
\hline Sangat tidak setuju & 0 \\
\hline Tidak setuju & 11 \\
\hline Tidak Tahu & 6 \\
\hline Setuju & 63 \\
\hline Sangat Setuju & 19 \\
\hline Jumlah & $\mathbf{1 0 0}$ \\
\hline
\end{tabular}

Tabel 2. Rekapitulasi urgensi pensi bagi siswa itu sendiri

Sampel siswa cenderung sangat tidak setuju (52\%) dan tidak setuju (45\%) bahwa pensi sekolah itu penting bagi pihak sekolah dan guru, sedangkan mereka cenderung setuju (63\%) dan sangat setuju (19\%) bahwa pensi itu penting bagi para siswanya. Di sini terdapat dua hal yang kontradiktif, di mana siswa tidak melihat pensi sekolah sebagai sesuatu yang dianggap penting oleh pihak sekolah dan guru, sedangkan hal tersebut penting bagi mereka. Di sini terlihat, bahwa siswa melihat urgensi sekolah dipandang rendah oleh pihak sekolah dan gurunya.

Berikut ini adalah rekapitulasi hasil pengolahan data terhadap variabel persepsi urgensi pensi untuk pertanyaan terbuka yang berisi kategor-kategori aktifitas yang dianggap lazim dilakukan saat pensi:

\begin{tabular}{|l|r|}
\hline \multicolumn{2}{|l|}{$\begin{array}{l}\text { Menurut kamu, apakah tujuan utama dari } \\
\text { diadakannya pensi di sekolah kamu? (harap } \\
\text { pilih satu saja, silakan tulis jawaban sendiri } \\
\text { jika pilihan yang tersedia tidak mewakili } \\
\text { jawabanmu) }\end{array}$} \\
\hline \begin{tabular}{l|r|} 
a. Ajang unjuk kreativitas & $\mathbf{3 0}$ \\
\hline b. Ajang eksistensi sekolah & $\mathbf{3 2}$ \\
\hline $\begin{array}{l}\text { c. Ajang menampilkan ekstra kurikuler } \\
\text { sekolah }\end{array}$ & $\mathbf{3}$ \\
\hline d. Melatih kepemimpinan & $\mathbf{2 4}$ \\
\hline $\begin{array}{l}\text { e. Melatih kemampuan event } \\
\text { organizing }\end{array}$ & $\mathbf{0}$ \\
\hline $\begin{array}{l}\text { f. Mencari dana dari sponsor dan } \\
\text { sumber lain untuk sekolah }\end{array}$ & $\mathbf{3}$ \\
\hline g. Ajang menghabiskan dana sekolah \\
\hline h. Lainnya
\end{tabular} \\
\hline
\end{tabular}

Tabel 3. Rekapitulasi urgensi aktifitas dalam pensi

Responden memandang bahwa pensi itu adalah ajang unjuk kreativitas (30\%), ajang eksistensi sekolah (32\%), dan ajang melatih kemampuan event organizing (24\%). Dapat disimpulkan bahwa gengsi almamater untuk eksis lewat ajang pensi, menjadi salah satu alasan utama 
diadakannya pensi.

\section{Pensi dan sumber daya}

Dimensi pensi dan sumber daya, dideskripsikan menggunakan dua item pertanyaan tertutup yang mencari tahu apakah persepsi sampel terhadap pensi dalam kaitannya dengan sumber daya uang dan waktu. Berikut adalah tabel rekapitulasinya:

\begin{tabular}{|l|r|}
\hline \multicolumn{2}{|l|}{\begin{tabular}{l} 
Pensi sekolah itu hanya buang-buang waktu \\
\hline Sangat tidak setuju
\end{tabular}} \\
\hline Tidak setuju & 16 \\
\hline Tidak Tahu & 61 \\
\hline Setuju & 15 \\
\hline Sangat Setuju & 7 \\
\hline Jumlah & 0 \\
\hline
\end{tabular}

Tabel 4. Rekapitulasi persepsi tentang pensi dan sumber daya waktu

\begin{tabular}{|l|r|}
\hline \multicolumn{2}{|l|}{ Pensi sekolah itu hanya buang-buang uang saja } \\
\hline Sangat tidak setuju & 10 \\
\hline Tidak setuju & 55 \\
\hline Tidak Tahu & 13 \\
\hline Setuju & 17 \\
\hline Sangat Setuju & 4 \\
\hline Jumlah & 100 \\
\hline
\end{tabular}

Tabel 5. Rekapitulasi persepsi tentang pensi dan sumber daya uang

Sampel cenderung tidak setuju (61\%) dan sangat tidak setuju (16\%) bahwa pensi itu sekedar buang-buang waktu dan juga tidak setuju (55\%) kalau pensi buang-buang uang, walaupun ada yang setuju bahwa pensi itu buang-buang uang (17\%). Secara konsensus, dapat disimpulkan bahwa sampel merasa bahwa pelaksanaan pensi sekolah, bukanlah sesuatu yang sifatnya penghamburan sumber daya, baik uang maupun waktu.

\section{Apresiasi Pensi}

Dimensi apresiasi pensi, dideskripsikan menggunakan dua item pertanyaan tertutup yang menanyakan tentang bagaimana sampel mengapresiasi pensi mereka sendiri, berdasarkan bintang tamu yang didatangkan dan dekorasi yang digunakan. Dua aspek ini, merupakan dua hal yang menurut Tisha Anwar menjadi tolak ukur kualitas pensi sekolah. ${ }^{2}$

Berikut ini adalah rekapitulasi hasil pengolahan data untuk dimensi tersebut:

\begin{tabular}{|l|r|}
\hline \multicolumn{2}{|l|}{ Pensi sekolah saya, jauh lebih keren dari pensi } \\
\hline Sangat tidak setuju & 1 \\
\hline Tidak setuju & 12 \\
\hline Tidak Tahu & 33 \\
\hline Setuju & 22 \\
\hline Sangat Setuju & 31 \\
\hline Jumlah & $\mathbf{1 0 0}$ \\
\hline
\end{tabular}

Tabel 6. Rekapitulasi apresiasi terhadap pensi sendiri, aspek bintang tamu

\begin{tabular}{|l|r|}
\hline \multicolumn{2}{|l|}{\begin{tabular}{l} 
lainsi sekolah saya, jauh lebih keren dari pensi \\
\hline Sangat tidak setuju
\end{tabular}} \\
\hline Tidak setuju & 8 \\
\hline Tidak Tahu & 36 \\
\hline Setuju & 25 \\
\hline Sangat Setuju & 29 \\
\hline Jumlah & 100 \\
\hline
\end{tabular}

Tabel 7. Rekapitulasi apresiasi terhadap pensi sendiri, aspek dekorasi

Sampel cenderung setuju (22\%)

2 Interview dengan Tisha Amelia Anwar, reporter Belia Pikiran Rakyat 
bahkan sangat setuju (31\%) mengenai bintang tamu pensinya lebih baik dibandingkan pensi sekolah lain, walaupun $33 \%$ sampel merasa tidak tahu. Mereka cenderung setuju (25\%) dan sangat setuju (25\%) bahwa dekorasi pensi mereka lebih bagus dan unik ketimbang pensi sekolah lain, meskipun 36\% siswa merasa tidak tahu. Dapat disimpulkan, kemungkinan sebagian besar sampel tidak tahu pemilihan bintang tamu sekolah lain, sehingga jawaban tersebut paling dominan. Namun sampel juga cenderung setuju dan sangat setuju bahwa bintang tamu pensi sekolah mereka lebih baik dibandingkan pensi lain. Hal yang kurang lebih sama juga ditemui pada pertanyaan sehubungan dengan dekorasi.

\section{Pensi dan Kompetensi}

Dalam dimensi pensi dan kompetensi, dua item pertanyaan tertutup berusaha untuk menjelaskan persepsi siswa sehubungan dengan kemampuan pengelolaan acara pensi sekolah. Berikut adalah hasil rekapitulasinya:

\begin{tabular}{|l|r|}
\hline \multicolumn{2}{|l|}{ Panitia pensi di sekolah saya punya kemampuan } \\
dan pengetahuan seputar event organizing yang \\
baik untuk menjadi panitia pensi \\
\hline Sangat tidak setuju & 1 \\
\hline Tidak setuju & 7 \\
\hline Tidak Tahu & 23 \\
\hline Setuju & 49 \\
\hline Sangat Setuju & 20 \\
\hline Jumlah & 100 \\
\hline
\end{tabular}

Tabel 8. Rekapitulasi persepsi kompetensi kemampuan dan pengetahuan event organizing

\begin{tabular}{|l|r|}
\hline \multicolumn{2}{|l|}{$\begin{array}{l}\text { Panitia pensi di sekolah saya nggak perlu dapet } \\
\text { pelatihan/workshop event organizing buat jadi } \\
\text { panitia pensi }\end{array}$} \\
\hline Sangat tidak setuju & 13 \\
\hline Tidak setuju & 54 \\
\hline Tidak Tahu & 17 \\
\hline Setuju & 11 \\
\hline Sangat Setuju & 5 \\
\hline Jumlah & 100 \\
\hline
\end{tabular}

Tabel 9. Rekapitulasi persepsi kebutuhan mengikuti pelatihan event organizing

Sebagian besar sampel merasa bahwa mereka memiliki pengetahuan dan kemampuan mengelola event dengan baik, di mana $29 \%$ responden setuju dan $27 \%$ sangat setuju dengan pendapat tersebut, meskipun 30\% responden menjawab tidak tahu. Meskipun demikian 54\% responden menjawab setuju berkaitan panitia pensi perlu untuk mendapatkan pelatihan event organizing.

Dapat disimpulkan bahwa sampel merasa sudah memiliki kemampuan event organizing yang baik, meskipun mereka tetap merasa membutuhkan kegiatan pelatihan event organizing.

\section{Uji Pengetahuan}

Untuk mengkonfirmasi kognisi, maka penelitian ini melakukan uji pengetahuan terhadap sampel. Uji pengetahuan yang umum mengenai pensi, terkait tatacara, aturan, sponsorship, serta istilah-istilah yang lazim dalam event organizing. Pengetahuan diuji melalui 8 pertanyaan menggunakan jenis pertanyaan BenarSalah untuk selanjutnya diberikan skor 
(Sugiyono, 2003). Setiap jawaban yang benar diberikan skor 1 sedangkan setiap jawaban yang salah, diberikan skor 0 . Berikut adalah hasil pengolahan datanya:

\begin{tabular}{|l|r|r|}
\hline \multicolumn{1}{|c|}{ Topik Pertanyaan } & Benar & \multicolumn{1}{c|}{ Salah } \\
\hline Penggunaan Proposal & 93 & 7 \\
\hline Perizinan & 21 & 79 \\
\hline $\begin{array}{l}\text { Durasi Pensi yang } \\
\text { diperbolehkan }\end{array}$ & 48 & 52 \\
\hline Istilah event organizing & 22 & 78 \\
\hline Pengetahuan Logistik & 49 & 51 \\
\hline $\begin{array}{l}\text { Prosedur Perizinan Publikasi } \\
\text { Luar Ruang }\end{array}$ & 18 & 82 \\
\hline Dana Sponsorship Perusahaan & 16 & 84 \\
\hline Kewajiban Pajak & 43 & 57 \\
\hline Skor Total & 310 & 490 \\
\hline
\end{tabular}

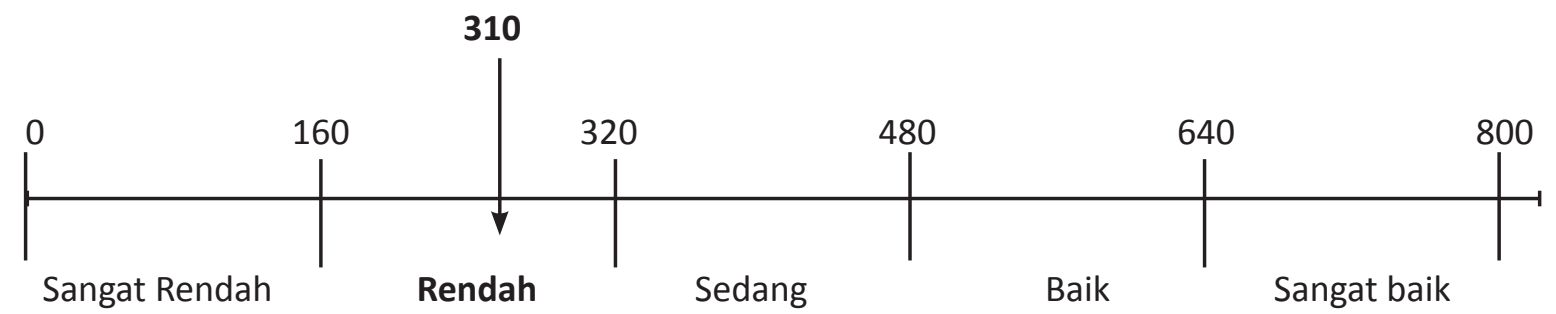
pengelolaan pensi berada di angka 310 . Dengan nilai skor total maksimal sebesar 800, maka dapat disimpulkan bahwa level pengetahuan sampel seputar pengetahuan umum yang berhubungan dengan pensi ada di level rendah, jika merujuk pada pembagian skor berdasarkan lima kuadran dengan rentang skor $800 / 5=160$. Adapun letak level pengetahuan sampel seputar pensi dapat dideskripsikan pada gambar berikut: 


\section{KESIMPULAN DAN SARAN}

\section{Kesimpulan}

Pensi sekolah dipersepsi sebagai sesuatu yang penting bagi siswa, namun siswa menilai pihak sekolah dan guru tidak menganggap pensi sekolah sebagai sesuatu yang penting. Ada dua hal yang kontradiktif dalam data ini. Perlu dikaji lebih lanjut, mengapa siswa memiliki persepsi demikian.

Pensi sekolah dianggap sebagai sebuah kegiatan yang tidak sekedar buangbuang sumber daya di mata siswanya. Dalam mengapresiasi pensinya sendiri, responden cenderung setuju bahwa pensi mereka lebih baik dibanding sekolah lain, meskipun angka yang menjawab tidak tahu juga tinggi.

Sehubungan dengan kompetensi mengelola kepanitiaan, responden cenderung merasa bahwa mereka mampu mengelola event, meskipun angka yang menjawab tidak tahu juga tinggi. Lebih lanjut, sebagian besar merasa mereka perlu mendapatkan pelatihan event organizing.

Meskipun mereka merasa mampu, namundalamkontekspemetaanpengetahuan siswa seputar pengelolaan event, level pengetahuan responden ada di angka yang cukup memprihatinkan, di mana melalui 8 item untuk mengukur pengetahuan mereka berkenaan pelaksanaan pensi yang benar, jumlah responden yang bisa menjawab dengan benar angkanya kecil, bahkan terbilang sangat kecil untuk beberapa item. Hanya dalam 1 item yang direspon dengan hasil benar yang sangat meyakinkan, berhubungan dengan penggunaan proposal.

Dengan demikian, dapat disimpulkan bahwa asumsi mengenai kurangnya pengetahuan siswa tentang tata cara pengelolaan sebuah event untuk pensi adalah benar.

Jika data yang telah didapatkan digunakan untuk merepresentasikan kondisi riil dilapangan, makaterdapatbeberapa issue yang sangat memprihatinkan berkenaan dengan pengelolaan pensi sekolah oleh para siswanya. Khususnya seputar pengetahuan mereka dalam mengelola sebuah event.

Yang paling perlu diperhatikan adalah temuan bahwa siswa merasa dirinya mampu, padahal dari pengukuran pengetahuan sederhana berkenaan pengelolaan event, hasilnya jauh dari skor yang memuaskan. Di sini, terdapat disparitas nyata antara persepsi siswa sehubungan dengan pengetahuan pengelolaan pensi, dengan kenyataan level pengetahuan mereka.

\section{Saran}

Pengelolaan pensi sudah menjadi hal yang lazim bagi beberapa sekolah, khususnya yang sudah memiliki tradisi pensi lama. Namun, perhatian dari pihak sekolah mengenai pentingnya memberikan bekal kepada siswanya masih minim. Untuk itu, perlu diberikan semacam kursus/ pelatihan event organizing bagi para siswa. Pola yang sekarang sering muncul, adalah hadirnya figur senior/alumni dalam membina/menjadi konsultan panitia (perlu data lebih lanjut), dan pihak sekolah/guru 
juga kurang memberikan pembimbingan secara intensif kepada panitia (perlu data lebih lanjut)

Perlu lebih banyak regulasi dan kebijakan yang perlu ditetapkan sehubungan dengan pengelolaan event (salah satunya pensi) di sekolah oleh siswa. Kebijakan dapat bersifat sektoral (sekolah) maupun terpusat (dari kemdikbud) terkait hal ini, sehingga tata-cara pengelolaan pensi dan hubungannya dengan pihak penyelenggara pendidikan jadi lebih ajeg dan terkendali. Misalnya, untuk memastikan pengawalan dari pihak guru terkait kepanitiaan event, guru yang diberikan tanggung jawab lebih, mungkin bisa diberikan insentif tambahan, karena membimbing penyelenggaraan event bukanlah tupoksi guru.

\section{DAFTAR PUSTAKA}

Kotler, Philip. (1993). Manajemen Pemasaran Analisis, Perencanaan, Implementasi dan Pengendalian. Universitas Indonesia. Jakarta

LaRossa, R., \& Reitzes, D. C. (1993). Symbolic inter- actionism and family studies. In P. G. Boss, W. J. Doherty, R. LaRossa, W. R. Schumm, \& S. K. Steinmetz (Eds.), Sourcebook of family theories and methods: A contextual approach. Thousand Oaks, CA: Sage.

Nasution, S. (1982). Teknologi Pendidikan. Bandung: Bumi Aksara

Notoatmodjo, Soekidjo. (2003). Pendidikan Dan Perilaku Kesehatan. Rinera. Cipta. Jakarta

Notoatmodjo, Soekidjo (2007). Promosi Kesehatan dan Ilmu Perilaku. Rinera Cipta. Jakarta

Supriya, Nana. (2009). Pendidikan Ilmu Pengetahuan Sosial. Bandung: PT Remaja Rosdakarya.

Sugiyono. (2011). Metode Penelitian Kuantitatif, kualitatif dan R \& D. Bandung

Sukmadinata, Nana Syaodih. 2006. Metode Penelitian Pendidikan. Bandung:Rosdakarya

Vincent, Gasperz. (1997). Manajemen Bisnis Total., Gramedia Pustaka Utama,. Jakarta.

West, Richard; Turner, Lynn H. (2010). Introducing Communication Theory: Analysis and Application. 4th. Ed. McGraw-Hill. New York

\section{Artikel Internet}


http://kbbi.web.id/

http://www.pikiran-rakyat.com/serial-konten/8671

http://beta286.print.kompas.com/muda/tag/sekolah/

http://beta286.print.kompas.com/muda/2015/01/23/pensi-ajang-pamer/

http://beta286.print.kompas.com/muda/tag/pensi/

http://www.hai-online.com/Hai/Feature/Skulizm/Sekolah-Lo-Mau-Bikin-Pensi-Hati-hatiSama-EO-yang-Lo-Pilih/

http://www.hai-online.com/Hai/Feature/Skulizm/Ketika-Guruku-Jadi-Makelar-Pensi

http://www.hai-online.com/Hai2/Topic-Of-The-Week/Tips-Konsep-Pensi-dari-Panitia-PLFair

http://www.hai-online.com/Hai/Feature/Skulizm/5-Cara-Biar-Pensi-Sekolah-Lo-Sukses/

\section{Interview}

Wawancara dengan Tisha Amelia Anwar, reporter Belia Pikiran Rakyat, 10 Agustus 2015, di kantor redaksi Pikiran Rakyat 